\title{
ETHNICITY AND POLITICAL TRANSITION PROGRAMMES IN NIGERIA, 1960-1999
}

\section{Chris Ojukwu and Oni Ebenezer Oluwole}

\author{
Chris Ojukwu is a senior lecturer in the \\ Department of Political Science \& International Relations \\ Crescent University, Abeokuta, Nigeria \\ email:chrisojukwu1@yahoo.com
}

Oni Ebenezer Oluwole is a PhD candidate in the Department of Political Science, University of KwaZulu-Natal, South Africa and a lecturer in the Department of

Political Science \& International Relations

Crescent University, Abeokuta, Nigeria

email:ebinotopsy9@gmail.com

\begin{abstract}
In Africa, ethnicity has become a versatile tool often used by elites and ethnic organisations to actualise their set goals. The phenomenon of ethnicity is also central to the analysis of Nigerian politics, given its plural nature. Since the commencement of the transition from colonialism to independence and from the guided transitions from military to democratic rule in 1999, ethnic identity and mobilisation have been prominent features of the political arrangement, with serious attendant consequences for political stability. The paper therefore examines some of the impacts of ethnicity on political transition in Nigeria particularly from 1960 to 1999. The methodology is both descriptive and analytical with data drawn extensively from documented sources and subjected to critical analysis.
\end{abstract}

Keywords: ethnicity, political transition, democracy, political acrimony

\section{INTRODUCTION}

Nigeria is a conglomerate society characterised by diverse types of socio-ethnic communities. These range from tribe to multinational groups with distinct cultural nuances that are expressed in varying institutional systems. The diversity and 
complexity of the various groups and the manner in which they influence political processes and decision making in the country have often been cited as the main obstacle against national integration in Nigeria.

As Joseph (1991, p. 48) points out, ethnicity remains a vital social force for several reasons: it is an emotionally satisfying mode of self- and group-assertion; and its salience increases rather than being 'voer-ridden' by division according to social class during the struggle for survival and material advantage in the modern sectors of society and the economy. It follows also that ethnicity is socially relevant when people unite and condition their actions on ethnic distinctions in everyday life. It is politicised when political coalitions are organised along ethnic lines, or when access to political or economic benefits depends on ethnicity (Fearon 2008). The point is that the ethnic factor and the centrifugal forces around it are perceived to be largely responsible for the death of genuine democracy. Suberu (1997, p. 341) captures it thus: Nigeria's deep ethnic, regional and religious cleavages and divisions have made the goal of institutionalising an enduring system of democratic governance paradoxically both structurally compelling and profoundly problematic.

Besides, the character of Nigerian politics has been informed by the global discourse on democratic transition. There are several strands to this discourse with particular reference to Nigerian experience. These include transferring power from colonial rule to indigenous or self-rule; from the military to civilian, that is demilitarisation; and from civilian to civilian (Anugwom 2001; International IDEA 2000 , p. 5). Importantly, Nigeria has experienced challenges in trying to attain an uninterrupted transition to democratic rule from the time of its creation as a nation-state by the British in 1914, until 1999. This is perhaps why it is argued that Nigeria's experience of the political transition to democracy has received more attention than any other country in the continent of Africa (Shettima 1995, p. 61; Agbese 1990, p. 23-24).

From the foregoing, the paper attempts to examine how ethnicity or ethnic politics has influenced political transition programmes in Nigeria, particularly from 1960 to 1999. The paper explores the impacts of the military, civilian elites and ethnic organisations on political transitions in Nigeria. In view of this, the paper is sub-divided into four sections: section one introduces the nature and objective of the paper; section two conceptualises ethnicity and political transition; section three identifies and analyses the phases of political transition in Nigeria and the impact of ethnicity on each of the phases; and section four concludes the study.

\section{CONCEPTUALISING ETHNICITY AND POLITICAL TRANSITION}

Depending on the analytical inclination of particular authors, and on the specifications and dynamics of particular situations, ethnicity has been attributed 
variously to the emotional power of 'primordial given' or cultural ties, the struggle for relative group with mass-based resource competition, elite manipulation, defective political institutions and inequitable state policies (Suberu 1996, p. 4). Amoo (1997) contends that several factors have combined to continue giving critical salience to ethnicity in the African polity. These include the artificiality of the African state, the absence of historical continuity in the political area that constitutes the modern state, the relative brevity and the superficiality of the colonial interregnum and the precipitate process of colonisation, the misgovernment and abuse inflicted upon the citizenry of many states, and the predatory nature of some of these states.

Ethnicity is partly perceived as the subjective symbolic or emblematic use of any aspect of culture by a group to differentiate itself from other groups. It is also viewed largely as an ideology of competition for increasingly scarce resources, which is a feature of colonial, post-colonial and strangeness of the state (Burgess 1978, p. 265-268; Mortimer 1999, p. 4; Hameso 1997, p. 5; Cohen 1969, p. 5). For instance, Nnoli (1978) argues that during the colonial period in Africa, competition for employment led to the phenomenon of urban ethnicity in which groups of migrant workers competed for jobs with better rewards on the basis of arbitrary connections made between tribes and occupation. The point Nnoli is stressing is that ethnicity is produced for its strategic utility in achieving material or political goods formally in the name of a group. But from an instrumentalist approach the concept can viewed as a consciously crafted ideological creation, not a natural cultural residue. Ethnicity is perceived to be the central unifying concept of African life, and it has been internalised to such an extent that Africans now think of the dynamics of their societies as being dominated by ethnicity. Osaghae (1991, p. 48-49) observes that resources that are usually used to pursue this goal include religious and ethnic groups, which form the gist of the conception of ethnicity as an ideology of inter-elite competition. He points out that elites are facilitated in this process by the marked inequalities which often exist among ethnic groups in terms of development.

In modern Africa, the need to compete for jobs and leadership positions compels individuals and groups to organise and mobilise themselves around ethnic organisations or movements in order to minimise their transition costs and maximise benefits accruing to them. In other words, competition for scarce resources induces individuals to form groups, develop political and ideological platforms, and to engage in conflict behaviour either through peaceful constitutionally prescribed methods, or through violence, in an effort to maximise benefits from such competition (Maku 2001; Nagel 1995). This, however, led to the emergence of many ethnic socio-cultural and political organisations and militias in the post-civil war Nigeria. 
To be specific, the Afenifere, Oodua Peoples Congress (OPC), Arewa Consultative Forum (ACF), Niger-Delta Volunteer Force (NDVF), Movement for the Survival of Ogoni People (MOSOP), Movement for the Actualization of the Sovereign State of Biafra (MASSOB) and Ohanaeze Ndigbo all champion the cause of their own ethnic interests through various means and approaches. The ACF, a group of highly visible northern emirs, former leaders, politicians and businessmen, emerged in 2000 in response to the loss of political power by the north. The main objective of the ACF is to foster and strengthen the foundation of northern unity in the context of one Nigeria. The Egbe Afenifere is a dominant ethnic organisation in the south west and is being controlled by eminent and affluent personalities. Its goal has remained the protection of the political, economic and social interests of the Yoruba. The Ohanaeze Ndigbo emerged in 1976 to protect and promote the collective interest of the Igbo and basically to serve as a social pressure group that seeks to influence the power structure in the country.

Indeed, the ethnic claims on the state in Africa, and particularly Nigeria, are tied to an ethno-structural imbalance among ethnic groups competing for the benefits of modernisation. This is typically for just and equitable political and bureaucratic representation, access to and allocation of scarce resources. Rothschild and Olorunsola (1983, p. 10) note that these claims and demands are reasonable to the extent that they do not threaten the legitimacy and existence of the state. But the characterisation of the Nigerian state as soft, weak, fragile, oppressive or failed, points to the inability of the state to satisfy the demands and expectations of citizens. This of course leads to ethnic rivalries and challenges, many of which ironically exploit state resources to sustain patronage networks. With fragile political institutions and weak national political cultures, the state has been transformed into an instrument for pursuing personal, ethnic and other sectional interests at the expense of other individuals and groups.

Increasingly, ethnicity has remained an important variable, as the ruling elite, whether constituted in the military or civil society, has consistently used it to feather their own nest - that is, elite domination. The colonial epoch not only magnified and concretised ethnicity (and presumed ethnic differences) in order to ensure dominance and control over the population, it also resulted in the 1914 amalgamation of Northern and Southern protectorates into a single geographical entity. From then on, ethnic groupings or nationalities have been jostling for increasingly shrinking economic, political and social advantages. Owing to this reality, it is argued that ethnicity negatively impinges on newly democratising societies such as Nigeria which have routinely vacillated between military and civilian rule. 
Nnoli (1994, p. 27) posits that access to state power is important for the various ethnic groups because of the extensive intervention of the African state in various spheres of the life of the African society, going beyond what is warranted by the character of the evolving welfare state. The common understanding is that access to state power enables influence to be wielded in virtually every facet of African life. For instance, state power could be used as an instrument to dominate, repress or physically eliminate individuals or groups from a juicy position. The same resources can be employed to assist mainly ethnic group members, which often results in ab unequal distribution of public goods (Eriksen 1993, p. 4; Esman 1994, p. 26). Relatedly, Eyoh (2002) stresses that nationalist elites or leaders capitalise on the privilege of succeeding the colonial masters in politicising ethnicity. Nationalist coalitions (typically with core regional support bases) disintegrated as the elite appealed to ethno-regional and kinship ties in the struggle for power and modern resources.

This brings into focus the concept of political transition. Political transition denotes a process of change from one form of government to another. It is a change from a military, dictatorial regime to either a civilian or a democratic government. According to Olagunju, Jinadu and Oyovbaire (1993), transition assumes a double meaning, namely transition from and transition to democracy. Transition from democracy simply implies the military take-over of government from the civilian, while transition to democracy implies the hand-over of government to civilian authorities.

Osaghae (2004) holds that political transition is a complex process. First, as reality - with changing processes, it introduces new beginnings and differentiates the past from the present and future in definitive ways. This is often demonstrated with new ground rules such as constitutions, pacts, negotiated settlements, agreements, regimes and the emergence of new actors and coalitions. Second, transitions are periods of turbulence and crisis. These generate tensions and uncertainties through the opening up of new opportunities for political access and competition, and also for ventilating frustrations, grievances and seeking redress, all of which encourage more intense and desperate political actions. Perhaps it is in this connection that O'Donnell and Schmitter (1986, p. 9-11) argue that the outcomes of transitions are extremely uncertain especially if they have to do with the transition to democracy.

In most African states, the transition from military to civilian rule is usually programmed in terms of its content, quality, duration and the level of participation by the state and civil society. This process is also almost always supervised by the military government in power. Even in retreat, the military may attempt to influence the composition and behaviour of the in-coming government, and are formidably equipped to destabilise or re-intervene against the new government 
especially if their (military) interests are threatened. The implication of this is that a failed political transition can lead to an unstable polity which in turn precipitates a coup d'état, thus introducing another round of military regime with its own new political transition programme; hence, the phrase 'transition without end' (Luckham 1998, p. 25-30).

Hermet (1991, p. 255) opines that the process of transition to democracy only comes to an end when that democracy has endeared itself with legitimate institutions and constitution, most particularly when the democratic leaders have their supremacy recognised by the army. Richard Joseph (1991) and Guy Martin (1993) assert that the transition to democracy in Africa is taking different forms and procedures at various speeds with different outcomes, depending on the nature of external inducements and on the configuration of domestic sociopolitical forces. Thus, they identify the following models of transition in Africa: national conference; government change via democratic elections; co-opted transitions; guided democratisation; recalcitrance and piecemeal reforms; and armed insurrection culminating in election and conditional transitions.

The national conference model expresses a situation where a broad coalition of civil society that invests itself with sovereign and supreme constitutional powers appoints a transitional government which organises and formulates guidelines for democratic elections. Such a process took place in the Republic of Benin where Mattieu Kerekou was removed from effective control of public policy to give way to multi-party elections in 1990. Government change through democratic elections describes a situation where a change of government is carried out through the normal process of electioneering, while a co-opted transition relates to a negotiated transition in which the opposition is co-opted into the ruling regime. Government via multiparty elections took place in Senegal in February 1988 and in Zambia in October 1991, while a co-opted transition took place in Gabon in September-October, 1990 and in Cameroon in October 1992. In guided democratisation, a military regime takes almost total control of the transition process which is usually perceived to be deliberate, complex and prolonged. This was the case in Nigeria during the military regimes of Ibrahim Babangida (1989-1993) and Sani Abacha (1994-1998).

It is instructive to note that there is often a synergistic interplay between ethnicity and political transition to the extent that the former influences and stimulates the latter. As Osaghae (2004) points out, one area in African politics where a complexity of transitions has had its full impact is that of ethnicity and ethnic conflict. This is so, considering the salience of ethnicity as an instrument of political competition and state organisation in several African countries. $\mathrm{He}$ also notes that political transition in Africa, and Nigeria in particular, has often elicited ethnic sentiments and triggered ethnic conflicts leading to the formation 
of mainstream and break-away or separatist ethnic political parties, associations, formal and informal ethnic pacts and settlements, and threats to national cohesion and stability. Corroborating this, Laakso and Olukoshi (1996, p. 15) submit that it is evident that ethnicity remains a significant legitimising political resource by civilian authoritarian and military regimes in Africa. They describe the situation thus: many African one-party and military regimes, despite their supposed aversion to ethnicity and despite their apparently secular character, rested on distinctly ethnic political foundations and reproduced themselves on the basis of definable, and in most cases narrow, ethnic alliance. At any rate, the role of ethnicity varies with different phases of the transition process. It is regarded as an appropriate instrument in the process of political succession or power contention. It has functioned primarily to consolidate the hegemony of the political class (Otite 1990 and Horowitz 1987).

Suffice it to say that transitions from military to civilian and from civilian to civilian find explanation in the participation of the electorate. The electorate who belong to various registered political parties is made to vote in order to give salience to democratic transition. In Africa, ethnicity affects voting behaviour. The phenomenon of ethnic voting occurs whenever members of a cultural sub-group show a disproportionate affinity at the polls for a particular political party. The logic of ethnic voting is that, by expressing group solidarity, sub-national groups seek to elevate leaders from their own cultural background into positions of power, especially the top executive spot, thereby gaining collective political representation (Horowitz 1985; Bratton and Bhavnani 2009). Importantly, voting behaviour in Africa has a predominantly ethnic explanation. Other factors include personal linkages and clientelism (Bratton and Van de Walle 1997). As a social cleavage, ethnicity has gained a prominent place in the understanding of politics in Africa. It is a powerful tool for voter alignment and even more so for party affiliation.

\section{THE NEXUS BETWEEN ETHNICITY AND POLITICAL TRANSITIONS IN NIGERIA (1960-1999)}

The general tendency in most of the transitional periods, especially in the colonial era, is to view political parties with an ethnic microscope and to infer their respective ethnic power bases from the ethnic affiliation of their leaders. When Nigeria's foremost nationalist leaders realised that there was a need to struggle for autonomy or self-rule, they had to come together to fight colonialism through their ethnically-based political parties. The key political parties then were the National Council of Nigerians and the Cameroons (NCNC) formed in 1944, The Action Group (AG) formed in 1951, and the Northern People's Congress (NPC) formed in 1949. 
The balkanisation of colonial Nigeria into three regions along ethnic, cultural and linguistic lines, under the Richards Constitution of 1946, laid the foundation of tribalism or ethnicity in Nigerian politics, leading to the emergence of regional and tribal politics. For instance, the NCNC outwardly wore a pan-Nigerian toga as a broad-based national party, even when its foothold or stronghold in a technical sense derived from the eastern region. The NPC, which was formerly a cultural organisation called Jami' yyar Mutanen Arewa, represented the collective interest of the north, while the AG which emerged in the west as an offshoot of a Yoruba cultural group, Egbe Omo Oduduwa, was also pro-Yoruba (Dudley 1982, p. 46-50).

It was within this same period of ethnic attachment to political parties that the concept of floor crossing was introduced into Nigerian political discourse. In 1951 some prominent Yoruba political elites exerted pressure on a number of Yorubas elected on the NCNC platform to decamp to the AG. This was in order to frustrate Dr. Nnamdi Azikiwe's chances of winning and becoming the premier of the Western Region, instead of Chief Obafemi Awolowo. Consequently Azikiwe was compelled to go back to the Eastern Region to forcefully remove Eyo Ita from his position as the leader of government. Eyo Ita was from a minority ethnic group in the then Eastern Region. Thus, 1951 marked the beginning of ethnic politics in Nigeria. This perhaps explains the coalition of the Eastern NCNC and the Northern NPC against the Western AG to form a central government when none of the parties produced a majority after the 1959 general elections. It may therefore not be out of place to reason that the political transition from colonial rule to independent Nigeria was on the basis of ethnic permutation and combination, a factor which eventually led to the demise of the First Republic.

The Murtala Muhammed/Olusegun Obasanjo transition (1975-1979) after the colonial era, was an opportunity for the civilian class to resolve its differences democratically and to compete for public office without threatening the stability of the political system (Oyediran 1997, p. 177). This regime was the only genuine effort after the collapse of the First Republic in 1966 to implement transition programmes that would culminate in the transfer of political power from the military to a civilian government. Murtala Muhammed ousted Yakubu Gowon on the grounds that Gowon had reneged on the promise of a transition to democracy. Having seized power in July 1975, Murtala Muhammed announced a five-stage, four-year transition programme to hand over power to a democratically elected government by October 1979. But on February 13 1976, Murtala was assassinated. The scepticism surrounding his death related to the ethnic factor.

The assumption was that the officers who prosecuted the killing were natives of Plateau states, a core sector of the Middle Belt where Gowon came from. The killers harboured a grudge against those in the military elite who were instrumental in the overthrow of Gowon. Following the demise of Murtala 
Mohammed, Obasanjo became the next head of state. In the process, he created 7 states in 1976 in addition to the 12 states created earlier by Gowon in 1972, which made the north/ south balance tilt in favour of the north in a ratio of 10:9. Perhaps it was for this reason that Omoruyi (cited in Ayoade 1998, p. 105) argued that the 19 states system constituted the greatest threat to a meaningful dialogue among Nigerians on the basis of equality of states, where states were supposed to be taken as units of representation. The 19 state structure overturned the previous equality between the North and the South.

On 21 September 1978, the ban on party politics was lifted, and this was followed by the registration of five political parties by the Federal Electoral Commission (FEDECO). The parties were the Unity Party of Nigeria (UPN), the National Party of Nigeria (NPN), the Nigeria Peoples Party (NPP), the Great Nigeria Peoples Party (GNPP) and the Peoples Redemption Party (PRP). In view of this, Ohanaeze Ndigbo, a socio-cultural organisation that binds the Igbo together, became involved in partisan politics. While some members of the organisation were wooed by the National Party of Nigeria (NPN), others identified with the NPP and a different group aligned with the Peoples Redemption Party (PRP). For instance, Alex Ekwueme identified with NPN on the basis of a realignment of political forces between the north and the east. Nnamdi Azikiwe and his group identified with the NPP on the grounds that they would utilise the opportunity to consummate the general amnesty and achieve reintegration into the Nigerian body politic on an equal basis with the other Nigerian communities (Joseph 1991, p. 99).

Jim Nwobodo and Sam Mbakwe, two staunch advocates of the NPP and former governors of Anambra and Imo states respectively, believed in the cause of realigning political forces in the country. It was their belief that through this realignment the Igbo would be fully reintegrated into the political mainstream of Nigeria. It was to this extent that the two governors wanted to link the progressive elements in Igboland with the progressive elements in Yorubaland on the one hand and with the progressive elements in the Fourth Dimension on the other, in an attempt to promote an alternative political party to the NPN after the 1979 election.

In the 1979 presidential election, statistics show that the NPN had $47.21 \%$ in the North, UPN had 5.02\% and NPP had 3.20\%. In the West, UPN had 85.03\%, NPN had $11.32 \%$ and NPP had 2.19\%. In the East, NPP had $84.73 \%$, NPN had $11.20 \%$ and UPN had $0.69 \%$ (Okpu 1989, p. 347-383). The results indicated or reflected the potency of ethnic identity and consideration and the nature and character of voting behaviour in contemporary Nigeria. Thus, political transitions in 1979 further accentuated the tripartite ethnic configurations exemplified by the three hegemonic ethnic groups and their political party support base, upon which the independent Nigerian state was created. 
During the Ibrahim Babangida transition (1985-1993), the ban on political activities was lifted in 1989, a situation whereby the political class was allowed to form political associations and to seek registration as political parties. In the process over 30 political associations were formed. The significant aspect of this was the extent to which ethnic and regional interest tended to determine or inform the nature of political alliances for most of the political associations. For instance, the People's Front of Nigeria was led by Retired General Yar'Adua, a key Northern politician and financier of the association. The People's Party was shaped by Igbo business magnate Dilllibe Onyeama, and the National Union Party was organised around Fola Akinsola, a Yoruba (Egwu 1998, p. 20-24).

Egwu (1998, p. 18) argues that the salience of ethnicity in this phase of the transition programme could be expressed in two ways: first, there was a remarkable absence of class-based or ideological politics which would have had the effect of providing alternatives to ethnic mobilisation. Babangida defined ideological debates as a no-go area, and consistently waged war against radicals, extremists and all those who articulated leftist political views. Second, was the visible role played by some individuals who could hardly be separated from their ethnic origins, and their role in the construction of ethnic-based patron-client networks. In fact, amid scrambling for one political association or the other by politicians, Babangida dissolved all political associations on the grounds that old cleavages - ethnic, geopolitical, religious and class - emerged in the new political associations essentially to suppress and prevent them from promoting issue-based politics (Egwu 1998, p. 27).

Arising from this, Babangida announced two political parties, the Social Democratic Party (SDP) and the National Republican Convention (NRC), demarcated along the ideological lines of a 'little to the left' and a 'little to the right'. The recognition of only two political parties was said to be tied to the ethnic factor. This was to minimise the political effects of ethno-regional particularism, religious sectarianism and ideological extremism, and also to balance the ethnoreligious equation in Nigeria (Sklar 1997, p. 35; Ihonvbere and Vaughan 1995, p. 77).

Meanwhile, the role played by Chief Arthur Nzeribe through his Association for Better Nigeria (ABN), preparatory to the presidential election in June 1993, was not only political but also largely ethnic. On June 101993 , a case was brought before Justice Bassey Ikpeme at the Abuja High Court by ABN, restraining the National Electoral Commission (NEC) from holding the presidential election. Though the NEC did not take the court injunction seriously as it went ahead with plans to conduct the election on June 12 1993, the cancellation of the election by Babangida indeed generated heat and incited bitter ethnic, regional and populist sentiments. Studies show that Nzeribe decided to frustrate Abiola's ambition because he claimed that he could do without the Igbo and he (Nzeribe) wanted 
to prove that Abiola would not succeed without the Igbo (Elesho and Ogunnaike 2000, p. 18).

In the same vein, Emeka Odumegwu Ojukwu was conscripted by the Babangida administration to canvass Igbo support for the annulment of the June 12 election on the grounds that the Yorubas did not support the Igbos during the Nigerian civil war. According to Lewis (1994, p.327), 'the president's repudiation of the election was especially provocative in view of the political volatility of the Yoruba region'. It reminded the nation of the electoral fraud and political exclusion that led to the breakdown of the first and second republics. The violence prompted a mounting exodus from the major cities, as southern ethnic groups, fearing a recurrent of the communal purges which preceded the 1967 civil war, fled to their home regions.

Shortly after the announcement that election results had been suspended, some western (Yoruba) leaders issued a statement urging that the results should be released. This calls into question whether Abiola, who was the presidential candidate of SDP, was representing only Yoruba interests or was the candidate of a national political party. The Kano people, for instance, voted massively for Abiola in opposition to Tofa, their own son in the eyes of ethnic chauvinists. As Toyo (1994, p. 63) remarks, what message about voting or political behaviour or about Nigeria were the chauvinistic Yoruba leaders sending to the Kano people or to other parts of Nigeria that voted for Abiola?

Toyo (1994, p. 64) further pointed out that earlier in the transition crisis, when Emeka Odumegwu Ojukwu was disqualified by the National Electoral Commission from becoming a presidential candidate, he claimed that he was discriminated against because he was Igbo. It did not occur to him that Igbos other than himself were found qualified enough to be allowed to contest, or that there other non-Igbos who were also denied the opportunity of contesting. It also did not matter to him that the chairman of the NEC then was Igbo. One may also add that Emeka Odumegwu Ojukwu on the NPN platform lost to Dr. Edwin Onwudiwe of NPP in Ojukwu's home town, Nnewi, in the 1983 senatorial election, indicating that Onwudiwe was more acceptable than Ojukwu in Nnewi.

Amid increasing tension and agitation against the annulment of the June 121993 election, Babangida appointed Chief Ernest Shonekan as the head of the interim government. This man, who had neither a political base nor control of the military, was perceived as a way of appeasing the south-west. Kukah (2000, p. 108) captures the scenario thus:

General Babangida had chosen him ostensibly to pacify the Yorubas and by extension neutralize whatever residual sentiments remained 
for Abiola. He hailed from Yoruba ethnic group like Abiola and both are of the same stock ... there is really no cause for worry because the Yoruba could not turn around and say that they had been denied the presidency on ethnic grounds.

Omo Omoruyi in his book, 'The Tales of June 12 - the Betrayal of the Democratic Rights of Nigerians' (cited in Irukwu 2007, p. 264-265), accused Professor Ben Nwabueze of being one of the lawyers who had encouraged Babangida to annul the June 12 election. They assured him that they would provide strong legal evidence to assist him find a reasonable and authoritative legal basis for nullifying the election. Omoruyi maintained that this legal opinion was a betrayal of the transitional project and democratic rights of Abiola and the Yoruba race, and one capable of increasing the dislike of the Igbo by the Yorubas (cited in Irukwu 2007, p. 264-265). In view of this, Irukwu reacted that the democratisation process did not derail because of any intervention by some Igbos. Instead, it failed because those in power wanted it to fail and they gave their reasons for that. He puts it succinctly thus:

Nigerians know all those responsible for the annulment of the June 12 elections and the responsibility should be placed squarely where it rightly belongs, instead of attempting to find some scapegoats amongst the Igbos thereby attributing their action to some kind of organized Igbo action resulting in the so-called Yoruba-Igbo feud. Though some Igbos may have played some negative and popularly unacceptable roles in the transition process they seem to have acted on their own probably as friends of General Babangida, but certainly not on account of any organized Igbo action designed to support the annulment of the June 12 election. This is simply because millions of Igbos voted for Abiola and supported him to the end in order to demonstrate their commitment to the democratic process'

Irukwu 2007, p. 264.

One element to be deduced from the foregoing is that Babangida's political programmes and particularly the June 121993 presidential election, arguably the freest and fairest in Nigeria's political history, were sacrificed on the altar of ethnicity. After this, the Sanni Abacha regime (1994-1998) also witnessed ethnic colouration. To consolidate his power, and realising that the greatest opposition to his regime would come from the western part of the country, Abacha picked his number two man or deputy from the west - Lieutenant General Oladipo Diya. Later, he appointed a cabinet that cut across ethnic groups. For instance, 
he appointed Ambassador Kingibe (North) as Minister of Foreign Affairs, a prominent pro-democracy lawyer, Olu Onagoruwa (West) as Minister of Justice, and Kalu I. Kalu (East) as Finance Minister (Lewis 1994, p. 329). After a while, the first set of ministers was dropped and replaced with hardliners. It is argued that in those new appointments, ethnic sentiments were applied to dilute ideology as long as they ensured the survival and legitimacy of the government.

It is pertinent to note that it was in Abacha's regime that the idea of dividing the country into six geo-political zones was actualised. Though the issue generated much tension and pressure between the geographical south and north of the country, particularly as regards a rotational presidency and power sharing at the federal level, the Abacha administration endorsed the recommendation. As Agbu (1998, p. 252) notes, the recommendation was predicated on the fact that the annulment of Abiola's victory had sharply questioned the overwhelming domination of political power at the federal centre by military officers and civilian politicians from the geographical north of the country, including the northern minorities.

Realising that Abacha was planning to become a civilian president, many individuals and ethnic groups rallied around the administration championing the Abacha-for-Presidency campaign. Some of these groups and individuals include the Youth Earnestly Ask for Abacha, (YEAA) led by Daniel Kanu, the Northern Radicals, New Dimension of Yoruba extraction led by Bamidele Olumilua former governor of the old Ondo state, Chief Arthur Eze and Arthur Nzeribe. The Northern Radicals were of the view that Abacha's self-succession was in the interests of national survival and unity. The New Dimension, on the other hand, was out to render its unalloyed support to the Abacha government and also to ensure that the anti-Abacha forces in Yorubaland were utterly frustrated. The group put its argument thus:

The west has wanted to give leadership, but it has not had the opportunity. So, must we be a member of this Nigerian community only if we can lead them? If we cannot lead them can we not be a part of them and be a good part of them? We no longer want to play the politics of exclusion

cited in TELL 13 January 1997

By the same token, the duo of Arthur Eze and Arthur Nzeribe sponsored about 50 Igbo persons to Aso Rock in order to support Abacha's ambition. Nzeribe argued thus: 'The delegation has come to inform you that the entire Igbo race is strongly behind you in your presidential ambition' (Bakoji and Nzenwa 1997). Corroborating this, Eze remarked: 'I do not want another civil war again. Any 
mistake now can lead to an unpalatable scenario like the Congo Brazzaville ... General Abacha had direction. He has already won peace for Nigeria' (Bakoji and Nzenwa 1997). As a result of this, some Ohanaeze Ndigbo chieftains, such as retired Justice Eze Ozobu and Professor Ben Nwabueze, came out to condemn the positions of Nzeribe and Eze and held that the Igbo were never in support of Abacha's presidential ambition. Nwabueze summarised the position of the Igbo thus:

We made it very clear to Abacha that we are not supporting his selfsuccession plan at all and so Ohanaeze was not in his good book because of the position we have taken. No doubt, some members of Ohanaeze leadership are sycophants. They are people who want to use that medium to project themselves to one political position or the other. The common Igbo man knows what Abacha is doing. If you go to the common Igbo, they do not need these people to tell them what to do. They are not even close to the grassroots and they have never spoken for the Igbo people before, rather they have been speaking for themselves

(cited in Ojukwu 2012)

The sudden and mysterious death of General Sani Abacha triggered the last political transition programmes that eventually ushered in the much anticipated Fourth Republic. At that point, General Abdulsalam Abubakar took over the reins of power on June 8,1998 . He constituted a new electoral body to be known as the Independent National Electoral Commission (INEC). This commission eventually registered three political parties - the Alliance for Democracy (AD), the All Peoples Party (APP) which later changed to All Nigerian Peoples Party (ANPP) and the Peoples Democratic Party (PDP). As Ojo (2004, p. 76) observed, the PDP is without doubt the new hegemonic party. The AD is little more than the old Action Group which metamorphosed into the UPN during the Second Republic. The PDP is a resurrection of the old NPC/NCNC alliance, which reincarnated as the NRC during the aborted Babangida regime. The implication of this rebirth is that instead of abolishing ethnicity in the Nigerian polity, military intervention has actually reinforced and consolidated the ethnic divide. During the political campaign that led to the 1999 presidential election, PDP brought in Obasanjo, a Yoruba, to be its presidential candidate. He defeated Alex Ekwueme in the nomination exercise while AD and APP nominated Olu Falae, meaning that the two presidential candidates were both Yoruba, an interesting political scenario. The two presidential candidates emerged from the south west as consensus 
candidates of their respective political parties to placate the south westerners for the annulment of the June 12, 1993 presidential election won by their kinsmen.

Obasanjo was also considered to have sold out to northerners; hence he received little or no support in the south west. In Lagos, for instance, Obasanjo only had 12 percent of the vote (Irukwu 2005, p. 157; Wright 2006, p. 676; Ojo 2004, p. 76). Some members of the Ohanaeze leadership advised the Igbo people not to vote for Obasanjo and his party, Peoples Democratic Party (PDP). The reason for this was that Olusegun Obasanjo never liked the Igbo. But the advice was apparently turned down as at the end of the day the south-east geopolitical zone voted massively for Obasanjo and his party. In sum, Abdul Salami Abubakar's political administration was largely informed by the need to ensure ethnic compensation and the balance of power, especially at the centre.

\section{CONCLUSION}

The paper set out to examine the salience of ethnicity in political transitions in Nigeria. It argued that in states where certain ethnic groupings are powerful, even dominant, national stability has been extremely precarious, as demonstrated in the various political transitions in Nigeria. It suffices to say that on one hand, ethnicity has played a destructive role in Nigeria's political transitions as it has contributed to the derailment of institutionalising and/or consolidating democratic governance in Nigeria. On the other hand, it catalysed (positively) the agitation for the restructuring of the Nigerian political system as crystallised in the creation of the six geopolitical zones: South-East, South-West, South-South, North-East, North-West and North Central.

The study revealed that through ethnicity, political associations and alliances display extensive traits of division between ethnic groups of the authoritarian regime. These comprise those ethnic groups that are perceived to be the principal beneficiaries of the policies of the regime, and those of the opposition, as played out by the Yorubas in the annulment of the June 12, 1993 election. More than any other group, the Yoruba did not take the situation lightly as they mounted pressure on the administration to reclaim its mandate. The Yoruba ethnic group, using Kuka's expression (2000, p.119), appropriated June 12 as its own property. Following this, the Abacha administration was conspicuously opposed in every possible way. 


\section{- REFERENCES}

Agbese, P 1991, 'The impending demise of Nigeria's forthcoming Third Republic', Africa Today vol. 37, no 3.

Agbu, O 1998, 'Political opposition and democratic transitions in Nigeria, 19851996', in AO, Olukoshi (ed), The politics of opposition in the contemporary Africa, Elanders Gofab, Stockholm.

Amoo, SG 1997, The challenge of ethnicity and conflicts in Africa: The need for a new paradigm, United Nations Development Programme, Emergency Response Division, New York.

Anugwom, EE 2001, 'The military, ethnicity and democracy in Nigeria', Journal of Social Development in Africa, vol. 16, no 2.

Ayoade, JAA 1998, 'The federal character principle and the search for national integration' in K Amuwo et al (eds), Federalism and political restructuring in Nigeria, Spectrum Books Limited, Ibadan.

Bakoji, S \& Nzenwa, L 1997, 'Abacha versus pro-democracy coalition'. Viewed 24 May www.gamji.com/aluko/aluko13.htm

Bratton, M \& Van de Walle, N 1997, Democratic experiments in Africa: regime transitions in comparative perspectives, Cambridge University Press, Cambridge.

Bratton, M \& Bhavnani, R 2009, 'Voting in Africa: ethnic, economic, or strategic?' paper presented at the Seminar on Africa, Department of Political Science, MTT, November 19.

Burgess, ME 1978, 'The Resurgence of Ethnicity: Myth or Reality?' Ethnic and Racial Studies, vol.1, issue 3.

Cohen, A 1969, Custom and politics of urban Africa, University of Chicago Press, Berkeley.

Dudley, BJ 1982, An introduction to Nigerian government and politics, The Macmillan Press, London.

Egwu, S 1998, 'Democracy at bay: Ethnicity and Nigeria's democratic eclipse 19861995', Afrigov Monograph, Series No 5.

Elesho, R \& Ogunnaike, A 2000, 'From obscurity to prominence', The News 22 May. Eriksen, TH 1993, Ethnicity and nationalism: Anthropological perspectives, Sterling Pluto Press, London.

Esman, MJ 1994, Ethnic politics, Cornell University Press, Ithaca.

Eyoh, D 2002, 'The ethnic question in African democratization experience', in D Eyoh, B Berman \& W Kymlicka (eds), Ethnicity and democracy in Africa, James Currey, Oxford.

Fearon, JD 2008, 'Ethnic mobilization and ethnic violence' in DA Wittman and BR Weingast (eds), The Oxford handbook of political economy, Oxford University Press, London. 
Hameso, SY 1997, Ethnicity in Africa: Toward a positive approach, Oxford University Press, London.

Hermet, G 1991, 'Introduction: The age of democracy', International Social Science Journal, vol. 12, no 8 .

Horowitz, DL 1985, Ethnic groups in conflict, University of California Press, Berkeley. Ihonvbere, J \& Vaughan, O 1995, 'Nigeria: Democracy and civil society', in J Wiseman (ed) Democracy and political change in sub-Saharan Africa, Routledge, London and New York.

International IDEA 2000 Democracy in Nigeria: Continuing Dialogue(s) for Nation Building. Capacity Building Series No 10.

Irukwu, JO 2005, Nigeria: The last chance, Spectrum Books Limited, Ibadan.

Irukwu, JO 2007, Nation building and ethnic organisations: The case of Ohanaeze in Nigeria, Spectrum Books Limited, Ibadan.

Joseph, R 1991, Democracy and prebendal politics in Nigeria: The rise and fall of the Second Republic, Spectrum Books Limited, Ibadan.

Kukah, MH 2000, Democracy and civil society in Nigeria, Spectrum Books Limited, Ibadan.

Laakso, L \& Olukoshi, AO 1996 The crisis of the post-colonial nation-state project in Africa, Nordic Africa Institute, Uppsala.

Lewis, PM1994, 'End game in Nigeria? The politics of failed Democratic Transition', African Affairs, vol.93, issue 372.

Luckham, R 1998, 'The military, militarization and democratization in Africa: A survey of literature and issues', in Hutchful and Berthily (eds) The military and militarism in Africa. CODESRIA, Dakar.

Martin, G 1993, 'Preface: Democratic Transition in Africa'. African Issue, vol. 21, no 1-2.

Mortimer, E 1999, People, nation and state: The meaning of ethnicity and nationalism, I. B. Tauris, London and New York.

Nagel, J. (1995). 'American Indian ethnic renewal: Politics and the resurgence of identity', American Sociological Review, 947-965.

Nnoli, O 1978, Ethnic politics in Nigeria, Fourth Dimension Publishers, Enugu.

Nnoli, O 1994, Ethnicity and democracy in Africa: Intervening variables, Malthouse Press Limited, Lagos.

O'Donnell, G\& Schmitter, PC 1986,Transition from Authoritarian Rule: Tentative conclusions about uncertain democracies, Johns Hopkins University Press, Baltimore.

Ojo, EO 2004, 'The military and political transitions', in AB Agbaje, L Diamond and E Onwudiwe (eds) Nigeria's struggle for democracy and good governance, Royal Bird Ventures, Lagos.

Ojukwu, CC 2012,'Ohanaeze Ndigbo and Political Transitions in Nigeria', Unpublished Ph.D Thesis, University of Ibadan, Ibadan. 
Okpu, U1989, ‘Ethnic minorities and federal character', in PP Ekeh and EE Osaghae (eds), Federal character and federalism in Nigeria, Heinemann, Ibadan.

Olagunju, T, Jinadu A and Oyovbaire S (1993),Transition to democracy in Nigeria (1985-1993), Safari Books/Spectrum Books Limited, Ibadan.

Olukoshi, AO \& Laakso, L (eds) Challenges to the nation state in Africa, Motala Grafiska Motala, Uppsala Sweden.

Osaghae EE 2004, 'Political Transitions and Ethnic Conflicts in Africa', Journal of Third World Studies vol 21, issue 1.

Osaghae, EE 1991, 'A Re-examination of the conception of ethnicity in Africa as an ideology of Inter-elite competition', African Study Monograph vol. 12, no 1.

Otite, O 1990, Ethnic pluralism and ethnicity in Nigeria, Shaneson C. I. Limited, Ibadan.

Oyediran, O 1997, 'Transition without end: From hope to despair, reflection of a participant observer', in PA Beckett and C Young (eds), Dilemma of democracy in Nigeria, University of Rochester Press, New York.

Rothschild, D \& Olorunsola, V (eds) 1983, State versus ethnic claims: African policy dilemmas. Westview Press, Boulder, $\mathrm{CO}$.

Shettima, KA 1995, 'Engendering Nigeria's Third Republic', African studies review vol.38, no 3.

Sklar, RL 1997, 'Crisis and Transitions in the political history of independent Nigeria', in PA Beckett and C Young (eds), Dilemma of democracy in Nigeria, University of Rochester Press, New York.

Suberu, RT 1996, Ethnic minority conflicts and governance in Nigeria, Spectrum Books Limited, Ibadan.

Suberu, RT 1997, 'Federalism, ethnicity and regionalism in Nigeria', in PA Beckett and C Young (eds), Dilemma of democracy in Nigeria, University of Rochester Press, New York.

TELL 1997, 'Interview with Bamidele Olumilua' 13 January.

Toyo, E 1994, Crisis and democracy in Nigeria: Comments on the transition from the Babangida Regime, Ahmadu Bello University Press, Zaria.

Wright, S 2006, 'The Government of Nigeria', in M Curtis et al. (eds), Introduction to comparative government, Longman, New York. 